\title{
A new species of Callistethus from Mexico (Coleoptera, Melolonthidae, Rutelinae)
}

\author{
Andrés Ramírez-Ponce ${ }^{2} \&$ Miguel Ángel Morón ${ }^{1}$
}

\begin{abstract}
IInstituto de Ecología A. C. Apdo. Postal 63, Xalapa, Veracruz 91000, México.miguel.moron@inecol.edu.mx
${ }^{2}$ Posgrado en Ciencias Biológicas. Instituto de Ecología. Universidad Nacional Autónoma de México. Circuito exterior s/n. Ciudad Universitaria, Copilco-Coyoacán, 04510, México D. F.
\end{abstract}

\begin{abstract}
A new species of Callistethus from Mexico (Coleoptera, Melolonthidae, Rutelinae). Callistethus tlapanecus, a new species collected in pine forest located at 2160 meters of altitude in eastern mountains of the state of Guerrero, Mexico is described. The morphological characters that distinguish it from other Mexican and Central American species are discussed. The diagnostic characters are illustrated, and a key to Mexican species of Callistethus is also included.
\end{abstract}

KEYWORDS. Central America; shiny chafer beetles; taxonomy.

\begin{abstract}
RESUMEN. Una nueva especie de Callistethus de México (Coleoptera, Melolonthidae, Rutelinae). Se describe Callistethus tlapanecus, nueva especie colectada en bosques de pino situados a 2160 metros de altitud en las montañas orientales del estado de Guerrero, México. Se comentan los caracteres morfológicos que distinguen a esta especie de otras especies mexicanas y centroamericanas de Callistethus. Se ilustran los caracteres diagnósticos y se incluye una clave para separar las especies mexicanas de Callistethus.
\end{abstract}

PALABRAS-CLAVE. Centroamérica; mayates brillantes; taxonomía.

The genus Callistethus was proposed by Blanchard (1851) and included only one species from Nepal, C. consularis Blanchard, 1851. Since then, a few other Asiatic species have been described in this genus, such as C. stoliczkae Sharp, 1878, C. seminitidus Fairmaire, 1889, C. pterygophorus Ohaus, 1903, and C. tumidicauda Arrow, 1912.

Machatschke $(1957,1972)$ transferred to Callistethus 130 Asiatic, African and American species originally described in the genera Anomala Samouelle, 1819, Euchlora MacLeay, 1819, Mimela Kirby, 1823, Popillia Dejean, 1821, Spilota Burmeister, 1844, and Spileuchlora Ohaus, 1903. Following the above cited author, Morón (1997) listed six Mexican species of Anomalini as members of Callistethus. Morón \& Nogueira $(1998,2002)$ recognized this genus as a valid taxon for the American fauna describing a new species, but Jameson et al. (2003) commented on the possible paraphyly between Anomala and Callistethus. However, our phylogenetic studies based on species of 18 genera of Anomalini from around the world supported the monophyly of Callistethus allowing a new diagnosis for it (Ramírez-Ponce \& Morón 2009).

Only two species with complete uniform coloration distributed in Mexico have the new diagnostic characters of Callistethus in agreement with Ramírez-Ponce \& Morón (2009): C. lepidus Burmeister, 1844 from the mountains of Guatemala and southern Chiapas, Mexico, and C. pseudolepidus Morón \& Nogueira, 2002 from the mountains of northern Oaxaca, Mexico. During the study of the Colección Nacional de Insectos, Instituto de Biología, UNAM (CNIN), we found specimens collected in the state of Guerrero, Mexico that represent a new species of Callistethus, described in this paper.
The terminology, characters and criteria used in the description are those of Ramírez-Ponce \& Morón (2009). In this work we applied the phylogenetic species concept (Wheeler \& Platnick 2000). Drawings were made with the aid of a camera lucida and stereomicroscope; measurements were obtained with an ocular micrometer and with electronic caliper. Photographs were taken with a multifocal microscope Leica Z16AP0A and a Leica camera DFC 490 using the Leica Application Suites software and form part of the "Irekani" digital database (http://unibio.unam.mx/irekani/index.jsp), under the coordination of the Unidad de Informática para la Biodiversidad (UNIBIO), Instituto de Biología, UNAM, Mexico. Studied specimens are deposited at CNIN (UNAM, City of Mexico) and at MXAL/IEXA (M. A. Morón collection, Xalapa, Veracruz, Mexico).

\section{Callistethus tlapanecus sp. nov.}

(Figs. 1-12)

Type material. Holotype and paratype. Holotype male at CNIN labeled (a) "México: Guerrero, Tlapa, Km 69 Tlapa-San Luis Acatlán desv. a Xochiatenco " $17^{\circ} 08^{\prime} 59$ "N, 98 $8^{\circ} 1^{\prime}$ ' 21"W, $2162 \mathrm{msnm}, 14 / \mathrm{VI} / 2006, \mathrm{H}$. Brailovsky y L. Cervantes" (printed), (b) our holotype red label (handwritten). Male genitalia card mounted. Paratype male at MXAL/IEXA, same data, except (b) our paratype yellow label (handwritten). Male genitalia and mouthparts card mounted.

Etymology. From indigenous nahuatl language "Tlapa", ancient name of the locality where the type specimens were collected; "tlapanecus" inhabitant of Tlapa.

Diagnosis. The new species is distinguished from $C$. lepida (Chiapas, México and Guatemala), C. pseudolepidus 
(Oaxaca, Mexico) and other species from Colombia, Costa Rica and Panama by the following combination of morphological characters: clypeus clearly subrectangular with straight anterior margin and surface with irregular dense, deep punctures; pronotum with abundant deep punctures; elytra with ten well marked longitudinal striae and apical calla much prominent; mesometasternal process long, slightly constricted near the base, in lateral view curved upwards with acute apex; metasternum with abundant yellow setae at sides; legs stout, with protarsi swollen; inner protarsal claw with lower bifurcation 3-4 times wider that the upper bifurcation; parameres short with apex sinuate and narrowed, with dorsal and ventral surfaces punctate; body color uniformly dark green.

Description. Holotype male. Form (Fig. 1): Elongate oval, apices of elytra broadly rounded, pygidium exposed beyond elytra; body length $14.3 \mathrm{~mm}$, humeral width $6.0 \mathrm{~mm}$. Color: head and body shiny dark green, antenna, apex of protibia, distal tarsomeres and tarsal claws in all legs dark reddish brown. Head: Clypeus trapezoidal, anterior border straight, lateral margins scarcely raised, surface of disc convex, dense, deep and irregularly punctate, some punctures are coalescent; marginal groove complete; sides weakly convergent from base; fronto-clypeal suture slightly sinuate. Frons with anterior shallow transversal depression near fronto-clypeal suture, with deep irregular punctures and three erect long supraocular setae at each side; posterior half of frons convex with deep scattered punctures. Eyes medium sized, weakly prominent; interocular distance equal to 5 dorsal ocular diameters; geno-occipital distance narrowed. Antennal club longer than length of scape, pedicel and funicle combined, curved in lateral view. Labrum wider than long, with anterior border slightly sinuate (Fig. 9). Mandibles with scissorial area widened with 3 apical teeth, upper tooth clearly larger than other teeth; external border of each mandible slightly

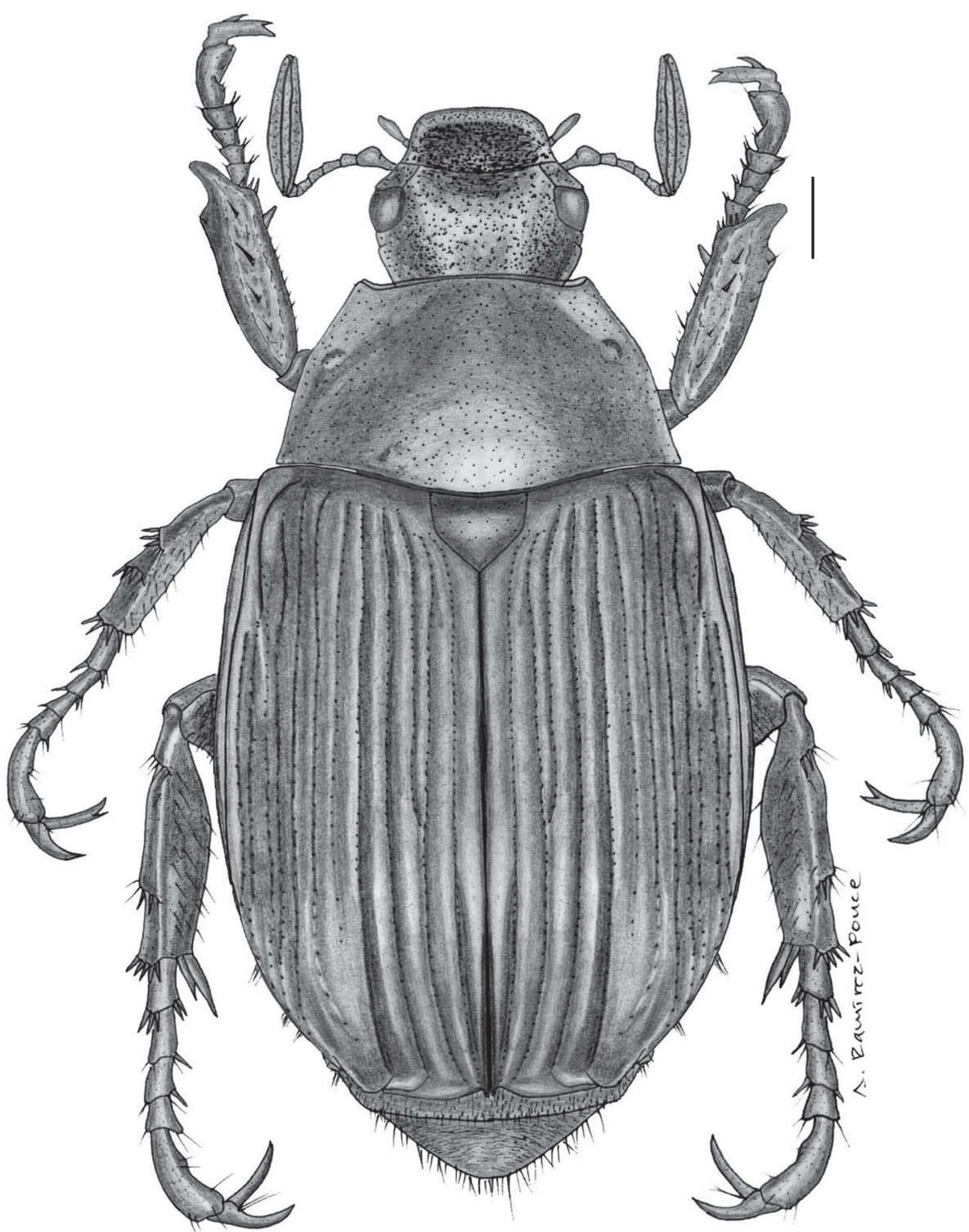

Figure 1. Dorsal view of the holotype of Callistethus tlapanecus sp. nov. Scale bar $1 \mathrm{~mm}$. 
angled; molar area widened with 9 transverse keels (Fig. 10). Lacinia with 6 sharply pointed, long teeth (Fig. 7). Labium briefly longer than wide, with sinuate anterior border; mesial surface marked; surface of prementum with noticeable declivity in relation to surface of mentum; disk of prementum with scattered setae (Fig. 8).

Pronotum. Surface convex, glabrous, with moderate punctures uniformly distributed and one marked lateral pit at each

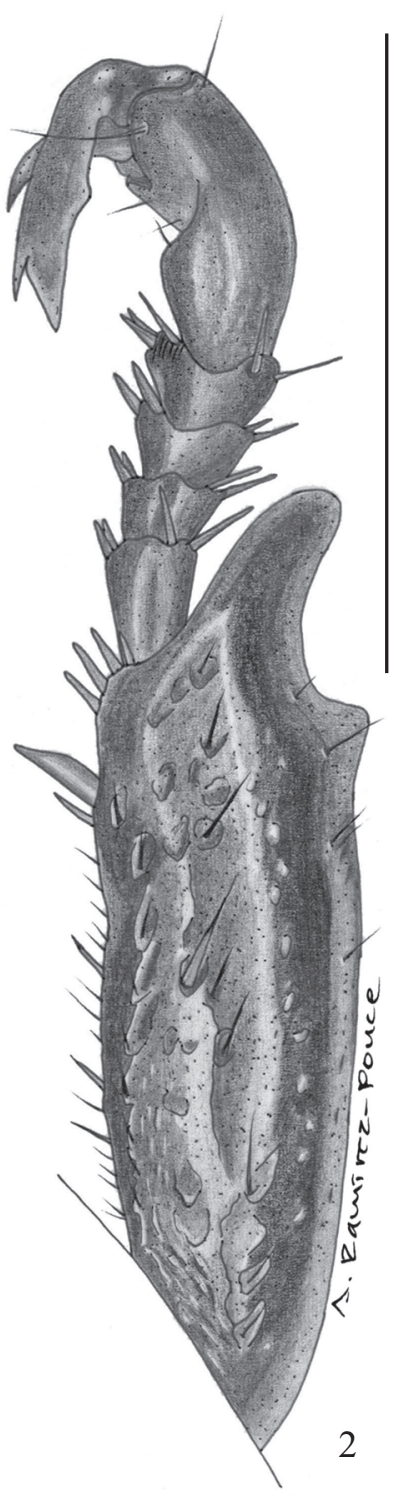

2
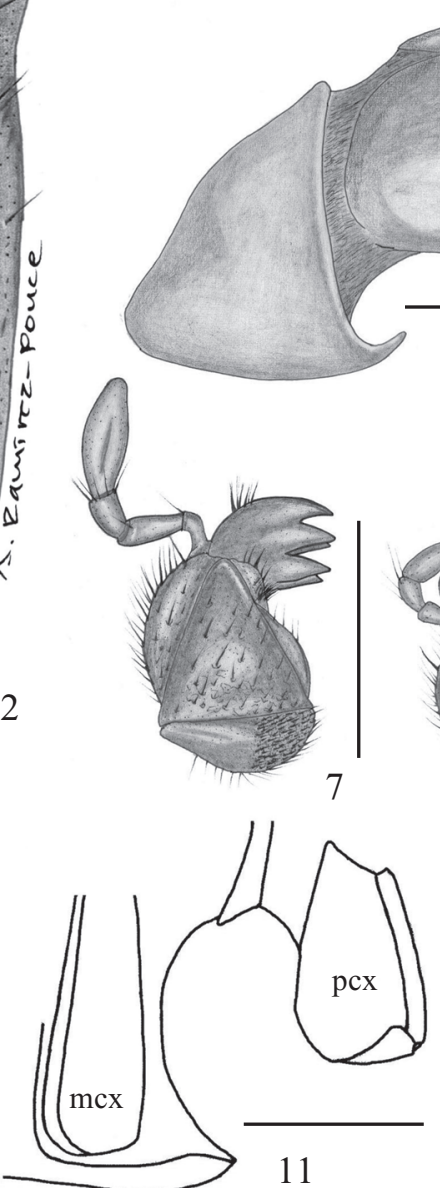
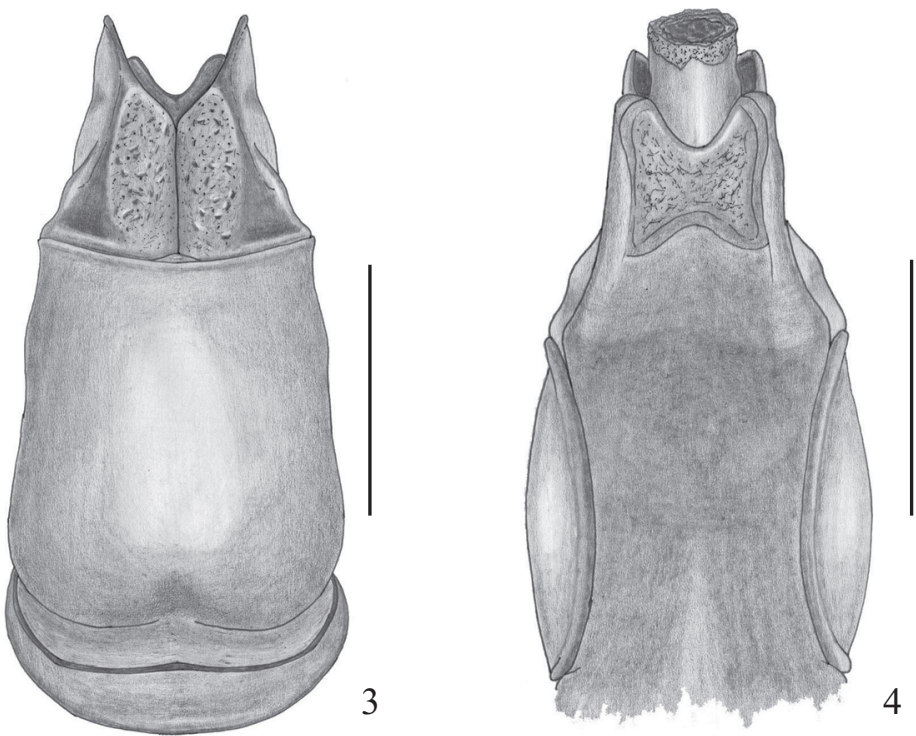

4
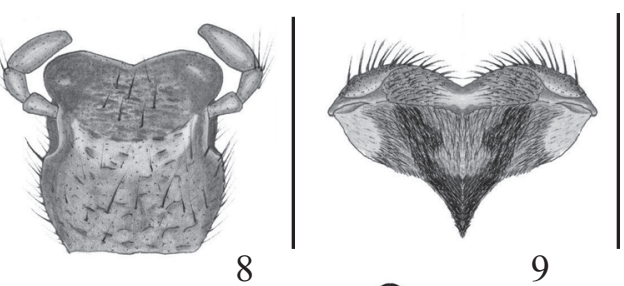

9

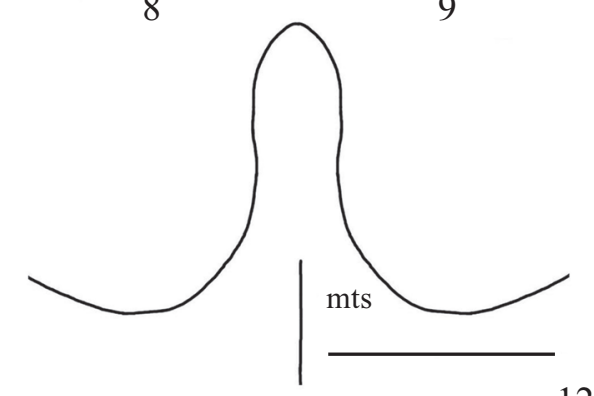

12

Figures 2-12. Diagnostic structures of Callistethus tlapanecus. 2, Right protibia and protarsus, dorsal view. Male genital capsule: 3, dorsal view. 4, ventral view. 5, lateral view. 6, Spiculum gastrale. 7, Right maxilla, ventral view. 8, Labium, ventral view. 9, Labrum, ventral view. 10, Right mandible, mesial view. Mesometaesternal process: 11 ) lateral view. 12 , ventral view. Abbreviatures: $\mathrm{mcx}=$ mesocoxa; $\mathrm{pcx}=$ procoxa; $\mathrm{mts}=$ metasternum. Scale bars: Fig. $2=2 \mathrm{~mm}$, Figs. $3-12=1 \mathrm{~mm}$. 
side; lateral borders slightly angled, with deep marginal sulcus complete, and 4 long setae regularly separated; anterior margin complete but weakly indicated near midline, preceded by cuticular rim in all the border; basal border moderately curved without margin. Anterior angles acute and prominent (Fig. 1).

Scutellum: briefly longer than wide (1.14:1) lateral borders slightly angled, without margins; acute apex; punctures less marked than in pronotum (Fig. 1).

Elytra: glabrous, with 10 deep longitudinal striae and well defined rows of punctures. Epipleural fold wide, with rounded border, clearly defined from humeral area to metacoxal area, much narrowed towards apical area, not evident near the apex; surface smooth with a complete row of short setae, each one separated from other by the length of one seta. Elytral suture clearly raised toward distal third, with spiniform apex. Apical calla prominent, acute; in dorsal view the apex protrudes elytral distal border (Fig. 1).

Sternal areas. Mesosternum with wide distance between mesocoxae and meso-metasternal process long, in ventral view slightly constricted at base, with rounded apex; in lateral view scarcely protrudes the mesocoxae, curved, with acute apex slightly directed upwards (Figs. 11-12). Metasternum densely punctate, covered with many yellowish long setae.

Abdomen. Surface of sternites with many punctures of different form and diameter; each sternite with one transverse row of medium size setae near the anterior border (lost near midline) and one transverse row of long setae on the posterior half. Anal plate with smooth surface and posterior border entire and prominent. Pigydial plate weakly convex, with strigulate surface, many short setae on the disk and preapical area, and long setae along the border.

Legs. Protibia widened, external border with elongate acute, apical projection clearly curved exteriorly, followed by a wide semitriangular sinus. Protibial spur straight, short (do not reach inner apex of protibia) much wider basally, with inner border gradually swelled to middle and abruptly narrowed towards the acute apex (Fig. 2). Protarsomeres $1^{\text {st }}$ $4^{\text {th }}$ much short and progressively widened (first tarsomere slightly longer than the others); apical tarsomere notably stout, as long as the preceding articles (Fig. 2). Inner protarsal claw much modified, strongly angled downwards, with a brief denticle near the middle of inner margin and bifid apex, lower projection longer and three times wider than the upper projection (Fig. 2). Mesotibia slightly widened on the middle; external surface with two noticeable oblique keels provided with spine-like setae. Mesotarsomeres $1^{\text {st }}-4^{\text {th }}$ short (first tarsomere slightly longer than fourth). External mesotarsal claw with bifid apex, lower projection two times wider than the upper; inner mesotarsal claw deeply cleft, notably curved towards distal half. Metatibia long and stout, little widened on the middle, external surface with two raised oblique keels provided with erect spine-like setae, and other small keel near the basal articulation, marked with three setiferous punctures; apical border with 15 spine-like setae; lower apical spur blunt, as long as first metatarsomere. Each metatarsal claws with different size, but both with apex entire.
Genital capsule. Length $3.06 \mathrm{~mm}$ (basal piece-tectumparameres ratio $=1.0: 2.13: 1.05)$ Tectum much convex, slightly narrowed distally (Figs. 3, 5); parameres shorter than tectum, with dorso basal surface coarsely punctate, apex narrowed and sinuate (Fig. 5). Ventral plate sclerotized, fused laterally with the parameres, distal half of surface punctate-rugose, apical border sinuate (Fig. 4). Spiculum gastrale with lateral sclerites much separate, subrectangular accessory plates dark colored with some long setae near distal border; basal sclerite straight and shorter than lateral sclerites (Fig. 6).

Variation. Paratype male. Body length $13.7 \mathrm{~mm}$, humeral width $6.0 \mathrm{~mm}$. Similar to holotype with the following exceptions: protibia with apical projection less curved; pronotum with external border slightly angled; body color uniform shiny bluish green.

Distribution. Known only from one locality at $2160 \mathrm{~m}$ high, between Acatlán and Xochiatenco, east of state of Guerrero, Mexico, near to Prioritary Terrestrial Region "Sierra TriquiMixteca" (CONABIO-RTP-126) characterized by pine forest, pine-oak and mesophilous forests, where specific richness and endemicity is high (Arriaga et al. 2000).

Comments. This new species of Anomalini is included in the genus Callistethus by the mesometasternal projection long and acute; dorsal integument metallic shiny; pronotum without basal margin; and genital capsule with ventral plate fused completely to the parameres. Callistethus tlapanecus sp. nov. share several characters with some Central American species of the genus, as with $C$. phosphorus (Bates, 1888) and $C$. xiphostethus (Bates, 1888) such as the increase of the dorsal sculpture, specially deep pronotal punctation, deep elytral striae; distal third of the first elytral interval raised with spine like apex; propygidium and pygidium shortened; and mesometasternal projection narrowed. Other Central and South American species of Callistethus similar to C. tlapanecus present more discrete sculpture on head, pronotum and elytra; rounded clypeus; pronotum with lighter color on lateral borders (also present in C. collaris Burmeister, 1844 and $C$. calonota Bates, 1888), hind angles rounded and lateral margins slightly angled; propygidium and pygidium enlarged, exceeding clearly the elytral apex; and mesometasternal projection widened and exposed, while other species as $C$. specularis Bates, 1888 and C. chrysanthe Bates, 1888, presents in addition to the lighter lateral edges of pronotum, the elytra intensely yellowish and the body size considerably larger.

Mexican species such as C. lepidus and C. pseudolepidus have genital parameres slightly compressed, while $C$. phosphorus and C. xiphostethus have parameres strongly depressed; C. lepidus, C. pseudolepidus and C. tlapanecus have uniform green dorsal coloration, while $C$. phosphorus and $C$. xiphostethus have the lateral edges of pronotum yellowish.

Into the Mexican species, C. lepidus is more similar to $C$. tlapanecus, sharing the body form, punctation and uniform color of the pronotum, increase of length of antennal club, size and form of the head, shape of meso-metasternal projection, and form of male genital capsule, but C. tlapanecus is easily differentiated from $C$. lepidus by its longer antennal 
club (in C. lepidus shorter than combined length of scape, pedicel and funicle), protarsomeres stout with ventral denticle on distal article broad (in C. lepidus the protarsomeres and ventral denticle are thin and rather narrow, respectively), and elytral striae are continuous (in C. lepida the striae are discontinuous).

\section{Key to the Mexican species of Callistethus}

1. Antennal club clearly shorter than the combined length of pedicel and funicle. Clypeus rounded. Pronotum nearly smooth, with weak minute punctures. Lateral borders of pronotum widely rounded. Elytra smooth, without striae. Mesometasternal projection widened with blunt apex. Upper part of the parameres nearly flattened. Northern Oaxaca ....... C. pseudolepidus Morón \& Nogueira, 2002

1 '. Antennal club clearly longer than the combined length of pedicel and funicle. Clypeus subrectangular. Pronotum clearly punctate. Lateral borders of pronotum angled. Elytra with deep longitudinal striae. Mesometasternal projection narrowed with acute apex. Upper part of the parameres raised

2. Anterior border of clypeus slightly curved. Antennal club slightly longer than the combined length of pedicel and funicle. Protarsomeres $1^{\text {st }}$ to $4^{\text {th }}$ narrowed. Elytral striae discontinuous, defined by shallow punctures. Southern Chiapas and Guatemala ...... C. lepidus Burmeister, 1844

2'. Anterior border of clypeus straight. Antennal club clearly longer than the combined length of scape, funicle and pedicel. Protarsomeres $1^{\text {st }}$ to $4^{\text {th }}$ notably stout. Elytral striae continuous, defined by deep punctures. Eastern Guerrero C. tlapanecus sp. nov.

\section{ACKNOWLEDGMENTS}

To Santiago Zaragoza-Caballero and Harry Brailovsky for the access to study the Colección Nacional de Insectos (CNIN) Universidad Nacional Autónoma de México (UNAM); to the former by the facilities with microscope equipment. The first author (ARP) express his gratitude to Postgraduate program in Biological Sciences UNAM and to CONACYT by the doc- toral grant that partially support the present study, to Atilano Contreras-Ramos (Instituto de Biología, UNAM) for the corrections to the first version of the manuscript, and to Susana Guzmán Gómez and Unidad de Informática de la Biodiversidad (Instituto de Biologia, UNAM, Mexico, D. F.) for technical support during image processing as a part of the project "Sistema de Informática para la Biodiversidad y el Medio Ambiente (SIBA)". This paper is a contribution to the project "Coleoptera Lamellicornia de América Latina" supported by the Instituto de Ecología, A.C. Xalapa (account 20030-10011).

\section{REFERENCES}

Arriaga, L.; J. M. Espinoza; C. Aguilar; E. Martínez; L. Gómez, L. \& E. Loa (coordinadores). 2000. Regiones terrestres prioritarias de México. Escala de trabajo 1:1 000 000. Comisión Nacional para el Conocimiento y uso de la Biodiversidad (CONABIO). México, 609 p.

Blanchard, C. E. 1851. Museum d'histoire naturelle de Paris. Catalogue de la collection entomologique. Classe des insectes. Ordre des coleóptères. Tome 2. Gide et Baudry, Paris, 111 p.

Jameson, M. L.; A. Paucar-Cabrera \& A. Solís. 2003. Synopsis of the New World genera of Anomalini (Coleoptera: Scarabaeidae: Rutelinae) and description of a new genus from Costa Rica and Nicaragua. Annals of the Entomological Society of America 96: 415-432.

Machatschke, J. W. 1957. Coleoptera Lamellicornia, Scarabaeidae, Rutelinae, Anomalini. Genera Insectorum 199B: 1-219.

Machatschke, J. W. 1972. Scarabaeoidea: Melolonthidae, Rutelinae. Coleopterorum Catalogus Supplementa 66: 1-361.

Morón, M. A. 1997. Rutelinae, p. 9-52. In: M. A. Morón, B. C. Ratcliffe y C. Deloya. Atlas de los escarabajos de México. Coleoptera: Lamellicornia. Vol. I. Familia Melolonthidae. Subfamilias Rutelinae, Dynastinae, Cetoniinae, Trichiinae, Valginae y Melolonthinae. Sociedad Mexicana de Entomología. México, 280 p.

Morón, M. A. \& G. Nogueira. 1998. Adiciones y actualizaciones en los Anomalini (Coleoptera, Melolonthidae, Rutelinae) de la zona de transición mexicana (I). Folia Entomológica Mexicana 103: 15-54.

Morón, M. A. \& G. Nogueira. 2002. Adiciones y actualizaciones en los Anomalini (Coleoptera, Melolonthidae, Rutelinae) de la zona de transición mexicana (II). Folia Entomológica Mexicana 41: 31-56.

Ramírez-Ponce, A. \& M. A. Morón. 2009. Relaciones filogenéticas del género Anomala Samouelle (Coleoptera: Melolonthidae: Rutelinae: Anomalini). Revista Mexicana de Biodiversidad 80: 357-394.

Wheeler, Q. D. \& N. I. Platnick. 2000. The phylogenetic species concept (sensu Wheeler and Platnick), p. 55-69. In: Q. D. Wheeler \& R. Meier (eds.). Species concepts and phylogenetic theory: a debate. New York, Columbia University Press, 230 p. 